\title{
Failure to find schedule-induced polydipsia in the pigeon
}

\author{
THOMAS ERIC WHALEN and DONALD M. WILKIE \\ University of British Columbia, Vancouver, Canada V6T 1W5
}

Food-deprived pigeons were exposed to fixed-interval food reinforcement schedules in test chambers in which water or grit was available. The intermittent food schedule did not induce reliable excessive consumption of either water or grit. This finding does not replicate an earlier report by Shanab and Peterson (1969) of schedule-induced polydipsia in the pigeon and adds another instance to the growing list of boundary conditions for schedule-induced phenomena.

If food-deprived but water-sated rats are given numerous small dry-food reinforcers (typically Noyes pellets) that are temporally spaced according to some schedule, they become polydipsic (Falk, 1961). The water consumption is excessive by several criteria. It is about 10 times the amount of water consumed if all the food is delivered at one time (Falk, 1967), about three to six times normal daily intake when the rat is at free-feeding weight (Falk, 1967), about five times the normal daily intake when the rat is maintained at $80 \%$ of free-feeding weight (Falk, 1964), and sometimes nearly half of the rat's weight (Falk, 1961).

While the phenomenon of schedule-induced polydipsia has been the subject of many investigations (see Falk, 1964, 1971, 1972 for reviews), very few studies have been concerned with the species generality of the effect. One of these (Shanab \& Peterson, 1969), which has been widely cited, claimed that pigeons, like rats, become polydipsic. This study, however, involved only one pigeon. Further, the bird's water consumption never approached the degree of excessiveness that characterizes the rat's behavior. The pigeon drank about $22 \mathrm{~g} /$ day in its home cage. When exposed to interval reinforcement schedules with interreinforcement intervals of $.5,1,2$, and $3 \mathrm{~min}$, the bird drank approximate averages of $16,19,34$, and $25 \mathrm{~g} /$ session, respectively. When food reinforcers were delivered at one time rather than being spaced, and when no food was given during sessions, the bird generally drank less than $20 \mathrm{~g} /$ session. However, since most of the latter data were collected with the water container in a different location in the test chamber than during the interval schedules phase, it is unclear if the bird's water con-

This research constituted the first author's MA thesis and was supported by a National Research Council of Canada scholarship and operating grant. T. Whalen is now at Dalhousie University, Halifax, Nova Scotia, Canada. Send reprint requests to Donald M. Wilkie, Department of Psychology, University of British Columbia, 2075 Wesbrook Place, Vancouver, British Columbia, Canada V6T 1W5. sumption during the interval schedules even exceeded that when meals were not temporally distributed or when food was absent.

The purpose of the present experiment was to provide additional data on the question of whether an avian species such as the pigeon will drink excessively when exposed to temporally spaced food schedules. Because pigeons also eat grit, or small pieces of rock and sand that grind against the grain in the crop, this experiment also searched for schedule-induced grit consumption.

\section{METHOD}

\section{Subjects}

Five White King pigeons, called WK7, WK10, WK17, WK28, and WK32, were maintained at $80 \%$ of their ad-lib weight (about $700 \mathrm{~g}$ ) by mixed grain. Water and granite grit were continuously available in the home cages. All subjects except WK32 had served in previous operant conditioning experiments. None had received water or grit outside of their home cages.

\section{Apparatus}

Two standard commercially obtained operant conditioning chambers for pigeons were ventilated with a fan and illuminated by a 7-W lamp. In each chamber, only the center of the three response keys was illuminated by red light from an Industrial Electronics Engineers' Series 10 projector. During reinforcement this key was turned off and grain was available in an illuminated food hopper located directly below the key. Either water or moist grit was continuously available in a glass container, $6 \times 8 \times 10 \mathrm{~cm}$ long, located in a rear corner of the chamber.

Schedules were programmed and data recorded with solid state and electromechanical circuits.

\section{Procedure}

Subjects WK7, WK10, and WK32 were placed in the test chamber for $2 \mathrm{~h}$ each day, 7 days/week, and the other subjects for $1 \mathrm{~h}$ each day, 5 days/week. Keypecks were reinforced with 5 -sec access to mixed grain after a fixed amount of time had passed since the previous reinforcement (a fixed-interval, or FI, schedule). During different conditions (see Table 1) either grit or water was present in the chamber and the value of the FI schedule was varied. A condition was terminated when the subjects' keypecking and water and grit consumption had been stable for at least 5 days, as determined by visual inspection.

When the above sequence of conditions was completed, the birds were given unlimited access to mixed grain, water, and grit. Water and grit consumption was measured daily. 
Table 1

Order and Number of Sessions Given Each Subject in Each Condition and Amount of Schedule-Induced Consumption

\begin{tabular}{|c|c|c|c|}
\hline $\begin{array}{l}\text { Interreinforce- } \\
\text { ment Interval } \\
\text { (min) }\end{array}$ & $\begin{array}{l}\text { Water (W) } \\
\text { or Grit }(G) \\
\text { Present }\end{array}$ & $\begin{array}{l}\text { Number of } \\
\text { Sessions }\end{array}$ & $\begin{array}{l}\text { Mean Con- } \\
\text { sumption } \\
\text { (g) }\end{array}$ \\
\hline
\end{tabular}

\begin{tabular}{|c|c|c|c|}
\hline (min) & Present & Sessions & (g) \\
\hline \multicolumn{4}{|c|}{ Subject WK7 } \\
\hline 2 & W & 14 & 0 \\
\hline 2 & G & 18 & 7.3 \\
\hline 2 & W & 7 & 0 \\
\hline 4 & $G$ & 10 & 5.6 \\
\hline 8 & G & 10 & 3.8 \\
\hline 16 & $\mathrm{G}$ & 10 & 5.7 \\
\hline 16 & W & 7 & .4 \\
\hline 8 & W & 7 & 0 \\
\hline 8 & $\mathrm{G}$ & 10 & 2.8 \\
\hline 4 & W & 8 & 0 \\
\hline \multicolumn{4}{|c|}{ Subject WK10 } \\
\hline 2 & W & 12 & 0 \\
\hline 2 & G & 17 & 15.0 \\
\hline 2 & W & 7 & 0 \\
\hline 4 & G & 10 & 16.2 \\
\hline 8 & G & 10 & 26.6 \\
\hline 16 & G & 10 & 9.6 \\
\hline 16 & W & 7 & 0 \\
\hline 8 & W & 7 & 0 \\
\hline 8 & G & 10 & 4.0 \\
\hline 4 & W & 8 & 0 \\
\hline 4 & G & 13 & 5.8 \\
\hline 2 & W & 7 & 0 \\
\hline 2 & $\mathrm{G}$ & 10 & 10.4 \\
\hline 1 & W & 7 & 2.8 \\
\hline 1 & G & 10 & 14.2 \\
\hline 2 & W & 10 & .4 \\
\hline 2 & G & 23 & 0 \\
\hline 4 & G & 28 & 1.0 \\
\hline 8 & G & 14 & 1.0 \\
\hline \multicolumn{4}{|c|}{ Subject WK32 } \\
\hline 2 & W & 28 & 3.2 \\
\hline 2 & G & 10 & 3.6 \\
\hline 4 & G & 14 & 3.0 \\
\hline 4 & W & 9 & 2.8 \\
\hline 8 & G & 8 & 2.6 \\
\hline 16 & G & 5 & 3.0 \\
\hline 4 & G & 9 & 2.8 \\
\hline 4 & W & 8 & 3.6 \\
\hline 2 & W & 7 & 2.4 \\
\hline \multicolumn{4}{|c|}{ Subject WK17 } \\
\hline 8 & $\mathrm{G}$ & 18 & 1.0 \\
\hline 8 & W & 8 & 2.4 \\
\hline 4 & $\mathrm{~W}$ & 11 & 1.8 \\
\hline 4 & $\mathbf{G}$ & 11 & 1.2 \\
\hline \multicolumn{4}{|c|}{ Subject WK28 } \\
\hline 8 & G & 12 & 1.0 \\
\hline 8 & W & 7 & 1.2 \\
\hline 4 & W & 13 & 1.4 \\
\hline 4 & G & 11 & 1.0 \\
\hline
\end{tabular}

\section{RESULTS AND DISCUSSION}

The different birds consumed an average of between 68 and $78 \mathrm{~g}$ of water and 1 to $4 \mathrm{~g}$ of grit per day under conditions of unlimited access to mixed grain, water, and grit. During test sessions only two of five subjects consumed more than their normal daily intake of grit. Even for these subjects, however, intake amounts were not always replicable.

Even less water was consumed during test sessions. Frequently, no measurable amount of water was consumed; at most, only a few grams were consumed. This absence of schedule-induced drinking in the pigeon also has been found recently in other laboratories (Dale, Note 1 ; Fraser, Note 2).

There have been other recent failures to find schedule induced polydipsia when the rat/dry-food reinforcer paradigm is abandoned. Wilson and Spencer (1975) recently failed to find schedule-induced polydipsia in the golden hamster. Symons and Sprott (1976) found schedule-induced polydipsia in some but not other strains of mice. Even in species such as the rat that show schedule-induced polydipsia, not all reinforcers have this effect (e.g., Allan, Porter, \& Arazie, 1975; Ramer \& Wilkie, 1977). These boundary conditions for schedule-induced polydipsia must pose a problem for most, if not all, contemporary theories that attempt to account for this phenomenon.

In comparison to the prototypal polydipsic subject, the rat, the pigeon's patterns of eating (Zeigler, Green, \& Lehrer, 1971) and drinking (Hawkins \& Corbit, 1973) are different. It has been suggested that differences in rat and pigeon drinking may reflect differences in kidney function (Hawkins \& Corbit, 1973). Factors such as these could conceivably account in some fashion for the absence of polydipsia in the pigeon.

\section{REFERENCE NOTES}

1. Dale, R. Schedule-induced drinking in the pigeon: Its temporal location and influences on operant keypecking. Unpublished Masters thesis, Dalhousie University, 1975.

2. Fraser, D. Unpublished manuscript. Dalhousie University, 1976.

\section{REFERENCES}

Allan, J. D., Porter, J. H., \& Arazie, R. Scheduleinduced drinking as a function of percentage reinforcement. Journal of the Experimental Analysis of Behavior, 1975, 23, 223-232.

FALK, J. L. Production of polydipsia in normal rats by an intermittent food schedule. Science, 1961, 133, 195-196.

FALK, J. L. Studies on schedule-induced polydipsia. In M. J. Wayner (Ed.), Thirst: First international symposium on thirst in the regulation of body water. New York: Pergamon, 1964. Pp. 95-116.

FalK, J. L. Control of schedule-induced polydipsia: Type. size, and spacing of meals. Journal of the Experimental Analysis of Behavior, 1967, 10, 199-206.

FALK, J. L. The nature and determinants of adjunctive behavior. Physiology and Behavior, 1971, 6, 577-588.

FALK, J. L. The nature and determinants of adjunctive behavior. In R. M. Gilbert \& J. D. Keehn (Eds.). Schedule effects: Drugs, drinking, and aggression. Toronto: University of Toronto Press, 1972. Pp. 148-173.

Hawkins, R. C., \& Corbit, J. D. Drinking in response to 
cellular dehydration in the pigeon. Journal of Comparative and Physiological Psychology, 1973, 84, 265-267.

RAMER, D. G., \& Wilkie, D. M. Spaced food but not electrical brain stimulation induces polydipsia and air licking. Journal of the Experimental Analysis of Behavior, 1977, 27, 507-514.

Shanab, M. E., \& Peterson, J. L. Polydipsia in the pigeon. Psychonomic Science, 1969, 15, 51-52.

Symons, J. P., \& SPRotr, R. L. Genetic analysis of scheduleinduced polydipsia. Physiology and Behavior, 1976, 17, 837-839.
Wilson, S., \& Spencer, W. B. Schedule-induced polydipsia: Species limitations. Psychological Reports, 1975, 36, 863-866.

Zeigler, H. P., Green, H. L., \& Lehrer, R. Patterns of feeding behavior in the pigeon. Journal of Comparative and Physiological Psychology, 1971, 76, 468-477.

(Received for publication May 16, 1977.) 